\section{Revista de Literatura, História e Memória}

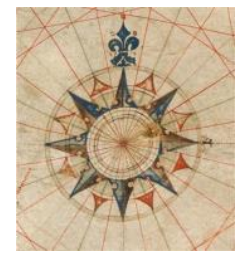

Dossiê: Literatura e interartes, desdobramentos estéticos e culturais: entrelaçamentos e reverberações da memória, da história, da sociedade e as identidades

ISSN 1983-1498

VOL. 16 - No 28 - 2020

U N I O E S T E / CA S C A V E L - p. 138-153

\title{
A REPRESENTAÇÃO DOCENTE EM DIÁRIO DE BITITA, DE CAROLINA MARIA DE JESUS
}

\author{
La representación docente en Diário de Bitita, \\ de Carolina Maria de Jesus
}

Lorena Ribeiro Melo ${ }^{1}$

RESUMO: Este artigo propõe-se a analisar a representação literária do docente em Diário de Bitita (2014), da escritora mineira Carolina Maria de Jesus. Buscaremos mostrar que a forma como a educadora é representada relaciona-se com o momento histórico em que estava inserida, a Primeira República Brasileira. Do mesmo modo, analisaremos os meandros de resistência simbolizados pela imagem da docente: a possibilidade, ainda que reduzida, de acesso ao mundo dos letrados para quem formava parte do universo da classe negra e pobre e a apropriação do letramento, enquanto forma de ascensão e como divisor social em uma sociedade que tinha uma grande parcela da população analfabeta. Partiremos, inicialmente, da problematização da escrita autobiográfica como viabilidade de representar a profissão de docente e seu contexto sócio-histórico. Por fim, mostraremos que o professor está representado tradicionalmente a partir de práticas pedagógicas conservadoras e autoritárias que, mesmo que limitadoras, permitem a aquisição do letramento como forma de resistência ao universo opressor da raça branca.

PALAVRAS-CHAVE: Autobiografia; Representação; Professor; Resistência; Carolina Maria de Jesus.

RESUMEN: Este artículo se propone a analizar la representación literaria del docente en Diario de Bitita (2014), de la escritora minera Carolina María de Jesús. Buscaremos mostrar que la forma como la educadora es representada se relaciona con el momento histórico en que estaba inserta, la Primera República Brasileña. De la misma manera, analizaremos los meandros de resistencia simbolizados por la imagen de la docente: la posibilidad, aunque reducida, de acceso al mundo de los letrados para quienes formaba parte del universo de la clase negra y pobre y la apropiación de la escritura y lectura, como forma de ascensión y como divisor social en una sociedad que tenía una gran parte de la población analfabeta. Partimos, inicialmente, de la problematización de la escritura autobiográfica como viabilidad de representar la profesión de docente y su contexto socio-histórico. Por último, mostraremos que el profesor está representado tradicionalmente a partir de prácticas pedagógicas conservadoras y autoritarias; y aunque limitadoras permiten la adquisión de la lectura y escritura como forma de resistencia al universo opresor de la raza branca.

PALABRAS CLAVE: Autobiografía; Representación; Profesor; Resistencia; Carolina Maria de Jesus.

As memórias de escritores têm sido cada vez mais registradas em romances memorialistas contemporâneos. No mesmo compasso, os estudos relativos a esse gênero levantam problematizações acerca deste tipo de narrativa, como suas particularidades e o

\footnotetext{
${ }^{1}$ Doutoranda em Literatura na Universidade de Brasília (UnB). É Mestra em Letras e Linguística - Área de Concentração em Estudos Literários, pela Faculdade de Letras - Universidade Federal de Goiás (UFG). Pprofessora titular de Língua Portuguesa e Espanhola no Ensino Médio Integrado a Cursos Técnicos e Literatura Portuguesa I no Curso de Licenciatura em Letras, no Campus Goiânia do Instituto Federal de Goiás.
} 
limite tênue entre o real e o ficcional. A exemplo deste entrelaçamento, Em Becos da memória (2017, p. 4), ao resgatar e relatar sua infância, Conceição Evaristo adverte seus leitores para que leiam sua obra como "ficções de memória". Na esteira das narrativas autobiográficas, Carolina Maria de Jesus, de igual modo, narra momentos vividos durante sua infância, que marcaram terminantemente sua vida, em Diário de Bitita, livro publicado pela primeira vez, postumamente, em 1982. A obra é composta por lembranças da infância da escritora mineira Carolina Maria de Jesus, cujo apelido era Bitita. Como a primeira idade mencionada da menina é de 4 anos: “- Que menina inteligente. E está com quatro anos. ” (Jesus, 2014, p. 14), temos, portanto, as narrativas de Carolina criança até tornar-se jovem, quando deixa o Estado de Minas Gerais para morar em São Paulo, a fim de trabalhar para uma professora que estava de mudança para a capital paulista.

Temos, na obra, a voz de uma criança negra e pobre denunciando a opressão imposta pelos brancos, ao documentar o preconceito, a injustiça social e a miséria aos quais foi submetida desde muito cedo. A autora, adulta, lança seu olhar subjetivo sobre sua meninice e demostra uma compreensão, permitida pela distância temporal do que viveu, de fatos que constituíram sua iniciação na vida social. A menina como portadora de sua própria história funda-se como a pessoa mais apropriada para desvelar sua trajetória. Diário de Bitita (2014) é um depoimento pessoal - por relatar sua intimidade, e social - por registrar acontecimentos sócio-históricos do interior do estado mineiro.

Carolina Maria de Jesus nasceu no interior de Minas Gerais, Sacramento, em 1914. De origem extremamente pobre, sobreviveu como doméstica e como catadora de papel, ocupação por meio da qual sustentou seus três filhos. Sua obra mais conhecida é composta por seus diários publicados em Quarto de despejo (2017) que relata sua vida repleta de privações e dificuldades, como moradora da favela do Canindé, em São Paulo. Similarmente, em uma “escrita de si" (ARFUCH, 2010), Diário de Bitita (2014) narra os acontecimentos anteriores à sua chegada em São Paulo.

O interesse e a escrita de gêneros autobiográficos como o diário, embora mais acentuados nos últimos tempos, não surgiu recentemente. Orest Ranum (1991) explica que cartas, autobiografias, agendas e memórias são formas de expressão de intimidade, já presentes na sociedade ocidental desde o século XVI. Por sua vez, Leonor Arfuch, em $O$ espaço biográfico: dilemas da subjetividade contemporânea (2010), engloba conceitos fundamentais para a compreensão dos gêneros autobiográficos. Arfuch focaliza a questão da subjetividade nas narrativas por meio de três aspectos: relato, razão dialógica e identidade. Segundo ela, esses gêneros contribuíram de maneira decisiva para o afloramento da 
concepção de subjetividade na escrita; enfatizando ainda que o surgimento dos gêneros autobiográficos se dá no século XVIII e está atrelado à consolidação da burguesia e do sistema capitalista. A autora acrescenta que Confissões de Rousseau foi o ponto de partida para a formação desse gênero que traz à tona o mundo privado e explicita: "Assim, confissões, autobiografias, memórias, diários íntimos, correspondências traçariam, para além de seu valor literário intrínseco, um espaço de autorreflexão decisivo para a consolidação do individualismo como um dos traços típicos do Ocidente" (ARFUCH, 2010, p. 36).

Philippe Lejeune é outro pesquisador e estudioso da escrita autobiográfica. Em $O$ pacto autobiográfico: de Rousseau à Internet (1990) expõe que nesse tipo de escrita existe o pacto autobiográfico: um tratado estabelecido entre o autor e o leitor, em uma ficção. $\mathrm{O}$ autor compromete-se a dizer a verdade sobre si mesmo, enquanto o leitor se compromete a aceitá-la com tal. Consequentemente, o leitor não espera ler uma ficção, mas sim a verdade sobre a vida de alguém. O pacto autobiográfico é, obviamente, imprescindível para a autobiografia. Esse pacto pode, por exemplo, ser firmado por meio de uma explicitação na capa, título, prefácio ou no início da narrativa. Ao respeito, Lejeune (1990 p. 23) afirma que o autor é a "única marca no texto de uma realidade extratextual indubitável, remetendo a uma pessoa real, que solicita, dessa forma, que lhe seja, em última instancia, atribuída a responsabilidade da enunciação de todo o texto escrito”. O autor explica como se segue, como se constitui, já no início do discurso autobiográfico, a identidade de nome entre autor, narrador e personagem:

[...] o narrador assume compromissos junto ao leitor, comportando-se como se fosse o autor, de tal forma que o leitor não tenha nenhuma dúvida quanto ao fato de que o 'eu' remete ao nome escrito na capa do livro, embora o nome não seja repetido no texto (LEJEUNE, 1990, p. 27).

Contudo, o teórico salienta que nem sempre os três elementos - autor, narrador e personagem - são coincidentes e concomitantes.

Compartilhando dessa relativização de Lejeune a respeito dos traços estruturais distintivos da autobiografia como gênero, Leonor Arfuch (2010, p. 56) aponta, ao perceber a dificuldade em encontrar uma fórmula clara e completa de narrações em primeira pessoa, como mais pertinente referir-se a "espaço autobiográfico, onde um tanto mais livremente, o leitor poderá integrar as diversas focalizações provenientes de um ou outro registro, o ‘verídico' e o ficcional, num sistema compatível de crenças”. Assim se tratando, a estudiosa relaciona, como se segue, as formas que compõem atualmente o espaço autobiográfico: 
Um primeiro levantamento não exaustivo de formas no apogeu - canônicas, inovadoras, novas - poderia incluir: biografias, autorizadas ou não, autobiografias, memórias, testemunhos, histórias de vida, diários íntimos - e, melhor ainda, secretos - correspondências, cadernos de notas, de viagens, rascunhos, lembranças de infância, autoficções, romances, filmes, vídeo e teatro autobiográficos, a chamada reality painting, os inúmeros registros biográficos da entrevista midiática, conversas, retratos, perfis, anedotários, indiscrições, confissões próprias e alheias, velhas e novas variantes do show (talk show, reality show), a videopolítica, os relatos de vida das ciências sociais e as novas ênfases da pesquisa e da escrita acadêmicas (ARFUCH, 2010, p. 60).

Adotando a concepção dos referidos autores, consideramos que Diário de Bitita (2014) está forjado neste espaço autobiográfico e, a partir de então, propomo-nos a pactuar com Carolina Maria de Jesus e tomar sua narrativa como realidades vivenciadas por ela em sua infância e adolescência. A partir de suas memórias registradas, adentramos o universo da menina inteligente com vocação para poetisa. Dentre os fatos marcantes, deter-nos-emos a sua ligeira trajetória escolar para realizar o presente estudo. Buscamos apontar em que momentos se dá a representação literária do docente na obra e analisar sua simbologia enquanto mediador da aquisição de uma ferramenta decisiva para o exercício da cidadania e dignidade humana na sociedade brasileira da época: a alfabetização. Pretendemos mostrar também como a representação do letramento de Bitita é uma forma de resistência ao mundo branco opressor que tolhia as oportunidades de acesso aos direitos e garantias fundamentais aos negros pobres. Para tanto, respaldar-nos-emos no aporte teórico relativo à representação literária, contexto histórico, letramento, metodologias de ensino e educação dos negros no Brasil.

Como método de trabalho, passamos, primeiramente, a contextualizar e relacionar os momentos da narrativa em que a imagem do docente e o espaço escolar estão representados na obra. Em seguida, faremos análise dessas situações à luz de pressupostos teóricopedagógicos, guiando-nos pelas metodologias de ensino e por estudos históricos.

Para analisar a representação literária a que nos propusemos, cumpre destacar sua relevância evidenciada na teorização de Luiz Costa Lima (1981, p. 3) a este respeito:

A representação é o produto de classificações. Ou seja, cada membro de uma sociedade se representa a partir dos critérios classificatórios a seu dispor. As representações são, por conseguinte, os meios pelos quais alocamos significados ao mundo das coisas e dos seres.

Assim sendo, a partir da representação que a autora Carolina Maria de Jesus faz de si e de seu universo, atribuímos sentido ao que é relatado. Em outro estudo, Luiz Costa Lima (2003) explica, ao relacionar a mímesis na modernidade à função poética, que a obra poética 
só é realizada quando recepcionada pelo leitor que dá sentido a ela e ativa a representação das distintas realidades ali existentes. Mostraremos, agora, em que momentos temos a representação do professor em Diários de Bitita (2014).

\section{O UNIVERSO ESCOLAR DE BITITA}

A obra narra, cronologicamente, em ordem linear, a trajetória da criança negra e pobre que enfrenta inúmeras adversidades em busca de sua sobrevivência em um mundo injusto, preconceituoso e desigual. Bitita, apelido de Carolina Maria de Jesus, morava com a mãe e o irmão, mas não conhecera seu pai, de quem sabia o nome, João Cândido Veloso, acrescido de poucas informações ao seu respeito. Sua referência paterna era o avô materno, Benedito José da Silva, a quem a menina devotava grande admiração; era seu defensor. Dizia ser ele o preto mais bonito que já tinha visto, além de considerá-lo um grande homem, pela honestidade e pelos cuidados que dirigia à família.

Nas memórias da autora, deparamo-nos com diversas situações vivenciadas por ela, desde as de ordem mais particulares até as sócio-históricas, constituintes de um depoimento pessoal e social. Temos registradas suas relações familiares; a suposta predileção da mãe pelo irmão; as brincadeiras com outras crianças; as divergências com outros membros da família,; a difícil convivência com a comunidade em que estava inserida; os conflitos com a polícia; a tradição religiosa; sua iniciação na escola; conflitos de classes e raças, entre o que ela denomina como predominadores e predominados; as reuniões com o senhor Manoel Nogueira que explicava sobre a conjuntura político-social do país; a revolução brasileira de 1930; a imigração de estrangeiros pra o país; a primeira guerra mundial. Assim, além de relatar muito de suas memórias infantis, a autora faz uma contextualização histórica, evocando com criticidade a luta de classes e o preconceito racial no Brasil, na primeira metade do século $\mathrm{XX}$.

A inteligência da menina é reiterada, bem como seu interesse pela leitura e sua inclinação para poetisa: “O senhor Barsanulfo disse-me que ela é poetisa! ” (JESUS, 2014, p. 18). Ainda bem pequena, por exemplo, Bitita invejava Isolina por ser alfabetizada e poder ler as receitas médicas para a vizinhança, quando prescritas pelos médicos. Ela era uma esperança para a menina que acreditava ter iguais condições de aprender a ler, já que Isolina era negra também.

Dentre os fatos narrados sobre a vida de Carolina Maria de Jesus, destacaremos, para análise neste estudo, a iniciação escolar da garota e sua consequente alfabetização realizada 
por sua professora Lonita Solvina. Pretendemos mostrar como a aquisição da leitura e da escrita foi fundamental para o desenvolvimento do gosto pelo ato de ler, para o começo da construção do repertório de leitura da autora e como representa um ato de resistência em uma sociedade racista. Entendemos que a ênfase dada à professora neste processo pode ser constatada também pelo fato de ter um capítulo dedicado a esse acontecimento "A escola". Capítulo no qual a escola está toda representada na imagem da referida docente. Não temos a representação de outros personagens da escola como diretores, coordenadores, demais professores ou outras figuras da gestão escolar. Assim, consideramos que a professora está representada na narrativa de Bitita como personagem central neste importante contexto escolar para a menina. De igual modo, associados e correspondentes à imagem da professora, temos a alfabetização e o letramento.

Desde o início do livro, são destacadas as lamentáveis circunstâncias do analfabetismo em que o Brasil se encontrava. Nenhum dos irmãos da mãe de Bitita estudou e seu avô, desgostoso, explicara-lhe a razão: "É que na época que os seus filhos deveriam estudar não eram franqueadas as escolas para os negros" (JESUS, 2014, p. 60). Outra situação que está em evidência é o analfabetismo dos policiais. Uma classe trabalhadora, que exercia um importante ofício de ordem e poder sobre a população, era composta por profissionais que não sabiam ler e escrever, em sua esmagadora maioria: "De duzentos homens, apenas dez sabiam ler" (JESUS, 2014, p. 31).

Ainda nesta mesma perspectiva, a própria menina conclui: "Percebi que os que sabem ler têm mais possibilidades de compreensão. Se desajustarem-se na vida, poderão reajustarse.” (JESUS, 2014, p. 129). Logo, inferimos que em uma sociedade na qual o analfabetismo era comum, aprender a ler e escrever era um desafio para o qual se atribuía valor ainda maior para quem o superasse e dominasse essas habilidades. Em um país que tinha deixado a escravidão tão recentemente, negros e pobres tinham limitado acesso à educação. Bitita, fatídica e não coincidentemente, acumulava as duas condições.

A autora traz à baila, em vários momentos, a problematização social sobre a restrição dos direitos sociais aos negros, principalmente aqueles relacionados à formação escolar. Essas questões sociais eram discutidas nos momentos em que os negros se reuniam com o senhor Manoel Nogueira. Ele era oficial de justiça e mulato, fato esse ressaltado pela narradora para explicar o motivo pelo qual podia conviver tanto com brancos quantos com negros, uma vez que o mulato era o "meio-termo da sociedade" (JESUS, 2014, p. 43)

Quando, por exemplo, se reuniam com o senhor Manoel Nogueira, a menina ouviu: “Tem um baiano, o doutor Rui Barbosa, que quer que o negro vá à escola, mas os brancos 
falam que já deram a liberdade para os negros e chega." (JESUS, 2014, p. 39). O senhor Nogueira lia para os negros (analfabetos) o jornal O Estado de São Paulo. Em diversos momentos como esses, através das discussões, ele ia ajudando-os a construir a consciência crítica de pertencimento de classe e de conjuntura político-social brasileira. Ele dizia:

Mas o Rui falava que a liberdade sem cultura e sem instrução não ia beneficiá-los. O negro inculto será nômade, indolente e imiscível. Não será um braço para impulsionar a nação. Será sempre uma boca. $\mathrm{O}$ analfabeto não tem forças para evoluir na vida. Ele será sempre um músico de ouvido (JESUS, 2014, p. 39).

Em uma dessas situações, Bitita constatou: "Eu notava que os pretos não sabiam ler. Nunca vi um livro nas mãos de um negro" (JESUS, 2014, p. 123). Pelo discurso da menina, notamos o quanto a leitura era tida como condição fundamental para se destacar na sociedade, como quando uma das pessoas que foi visitar o avô doente de Bitita comentou que diante de sua inteligência, só faltava ler para que ele fosse o "Sócrates africano" (JESUS, 2014, p. 122) e que havia sido "um crime" (JESUS, 2014, p. 122) seu avô não ter sido educado. E assim, a menina ia crescendo e percebendo as complexas dimensões sociais envolvidas no ato de ler e escrever. A alfabetização foi construída na narrativa como uma possibilidade de redenção e resistência do povo negro pobre. A partir destes trechos citados, podemos ter uma noção da exclusão vivida pelos negros em relação à educação, naquele contexto histórico.

Os estudos sobre a educação nos negros no Brasil são recentes e ainda precisam ser mais aprofundados. Segundo a pesquisadora Regina Pahim Pinto, somente nos anos 80 foram estabelecidas diretrizes para tratar das questões étnico-raciais na educação brasileira, após anos de reivindicações do movimento negro. Prova disso é que, recentemente, em 1992, a referida estudiosa denunciou a ausência da temática das relações entre educação e raça na história da educação (FONSECA; BARROS, 2016).

Ao recuperar a trajetória da educação formal no Brasil, Christianni Cardoso Morais (2016) nos mostra que a aprendizagem de escrita e leitura, até a metade do século XIX, ocorria de forma desarticulada: primeiramente se aprendia a ler e só depois, caso fosse possível, se aprendia a escrever, sendo que esse processo de aprendizado se dava em casa, com professores particulares ou em aulas públicas. E só após 1860, a "escolarização começa a ser vista como uma questão fundamental para a adaptação dos ex-escravos à nova sociedade que principiava a ser esboçada no Brasil, com base no trabalho livre” (MORAIS, 2016, p. 98). Foi somente em 1871 que a Lei do Ventre Livre dispõe sobre a obrigação legal da escolarização dos filhos dos escravos. A mesma autora pontua que, de acordo com Fonseca 
(2002), na primeira metade do século XIX, os escravos aprenderam a escrever e ler em lugares não escolares.

Cynthia Greive Veiga (2016) faz dois apontamentos importantes para a conformação do espaço escolar no período imperial e republicano brasileiros. Primeiro: desde o império estabeleceu-se uma tradição de designar as escolas públicas para as crianças pobres e negras e que já nos primeiros momentos da república conformou-se uma propensão de elitização e branqueamento da escola que permanecerá até a década de 1960.

A pesquisadora assinala que, mesmo sem dados quantitativos que possam mensurar a frequência de crianças negras na escola das primeiras décadas da República brasileira, "as mais variadas imagens dos alunos, especialmente dos grupos escolares, denotam um número majoritário de crianças brancas" (VEIGA, 2016, p. 273). De acordo com suas pesquisas, a estudiosa identifica a existência, neste mesmo período histórico, de uma ampla tensão racial nas escolas, notada nos conflitos travados entre pais e professores, alunos e professores e entre os próprios alunos, que agravavam o preconceito racial.

Ainda que não houvesse legislação, na história da educação brasileira, que impedisse as crianças pobres e negras de estudarem nas escolas, sempre existiram mecanismos velados e frequentes de exclusão para estes grupos sociais.

\begin{abstract}
Dessa maneira, ao ser anunciada a República, já se tinha um considerável acúmulo de experiências relativas aos processos de "evitação social" (ELIAS; SCOTSON, 2000) também no ambiente escolar. Esta experiência foi ampliada no contexto da elaboração dos testes escolares e instituição da escola seriada (grupos escolares) como práticas científicas de organização escolar. Para a escola pública deixar de ser indigente e viesse a se tornar referência de educação escolar, foi necessário que também a sua clientela fosse outra - crianças de famílias de "boa procedência" - pelo menos é o que podemos verificar em geral nos alunos das escolas públicas até por volta da década de 60 do século XX (VEIGA, 2016, p. 300).
\end{abstract}

Muito deste contexto histórico da educação dos negros no Brasil está representado na obra que analisamos. Bitita foi para uma escola kardecista, aos sete anos de idade, por incentivo de uma patroa de sua mãe, dona Mariquinha. Ela teve a oportunidade de acessar a escola, fundada pelo educador, político, jornalista e médium espírita Eurípedes Barsanulfo, por meio de um "apadrinhamento", uma ação social da francesa Maria Leite que dava roupas e livros novos para Bitita estudar. Inclusive, a mãe de Bitita colocou a filha na escola para não contrariar a benfeitora mulher representada com uma espécie de superioridade, ao ser rememorada enquanto branca e sábia.

A narradora relata que Bitita não gostou da escola inicialmente, primeiro por ser 
taxada como feia pelos colegas que a compararam com sapo, por conta dos olhos grandes; depois, porque a escola impossibilitava-a de mamar na mãe. A garotinha não tinha interesse pelos estudos e a professora procurava motivá-la para aprender a ler.

Parece-nos muito reveladora a significação desta professora para a menina. A professora é representada como uma profissional dedicada em seu ofício e insistente para que sua aluna aprendesse a ler. Preocupava-se com as faltas de Bitita: enviava um aluno em sua casa para investigar o motivo da ausência à escola e a elogiava dizendo que era inteligente. Os métodos de aprendizagem conservadores empregados, como levar "umas reguadas nas pernas" (JESUS, 2014, p. 127), aplicadas pela professora não impediram que a aluna nutrisse carinho por ela: "A minha professora insistia para eu aprender a ler. Me dirigia um olhar carinhoso.” (JESUS, 2014, p. 127). Bitita descreve a estratégia utilizada pela mestra para motivá-la nos estudos:

Ela percebendo que eu não me interessava pelos estudos desenhou no quadro-negro um homem com um tridente nas mãos que transpassava uma criança e disse-me:

- Dona Carolina, este homem é o inspetor. A criança que não aprende a ler até o fim do ano, ele espeta no garfo. No fim do ano, ele vem aqui e vou apresentá-la e pedir-lhe que dê um jeito na senhora, porque a senhora não quer estudar. Ele há de espetá-la no garfo.

Aquele desenho impressionou-me profundamente. Eu olhava o desenho e olhava o livro. Sonhava com o desenho e gritava:

- Mamãe! Olhe o inspetor! Mande o inspetor ir-se embora, que eu juro que hei de estudar. Eu vou aprender a ler. Não deixe ele espetar-me o garfo.

Mamãe dizia:

- Dorme, menina! Você está delirando! (JESUS, 2014, p. 126).

Mesmo após o momento histórico de substituição dos castigos físicos por outros métodos disciplinares nas escolas imperiais e mesmo após supressão e proibição no início da República, observam-se práticas disciplinares corporais pela via dos castigos físicos.

Ainda neste capítulo, temos narrado outro método usado pela professora para estimular os alunos a se dedicarem aos estudos:

A aula era mista. A minha professora dizia no fim da aula:

- Eu quero falar com os meus alunos pretos, é assunto muito importante.

Os brancos saíam, e nós ficávamos. Ela dizia:

- Estou notando que os meus alunos brancos são mais estudiosos do que os meus alunos pretos. Os brancos não erram quando escrevem. Lavam as mãos quando vão pegar os livros. Os desenhos então, que primor! Eles capricham e ganham cem todos os dias" (JESUS, 2014, p. 130).

Passados uns dias, ela pedia aos alunos brancos para ficarem na aula. Dizialhes que os alunos pretos eram os mais esforçados, os mais estudiosos, os 
mais capacitados nos deveres escolares.

- Eles vão passar de ano e vocês brancos vão repetir. Vai ficar ridículo para vocês, porque todos pensam que o branco é mais inteligente do que o preto. Estou encantada com o progresso dos meus alunos pretos.

Os alunos brancos saíam da aula revoltados.

Cada um ia comentando:

-Imagine só, o negro querer ser maior do que eu. Maioral tem que ser eu, que sou branco. Esses negros vão me pagar! (JESUS, 2014, p. 130).

Essas atitudes da professora Lonita evidenciam a metodologia e as práticas pedagógicas usadas por ela no processo de ensino-aprendizagem de seus alunos, que abordaremos no tópico seguinte.

\section{A REPRESENTAÇÃO TRADICIONAL DO DOCENTE NA OBRA}

A escola representada na obra situa-se, temporalmente, em 1921, ano em que Bitita começou a estudar. Compreende historicamente, a Primeira República Brasileira (1889-1930), período em que, segundo Jorge Nagle (1974), foi uma fase de reintrodução dos princípios liberais no Brasil que trouxe consequências para os setores econômico, político, social e cultural. Este último abrange o elemento da escolarização, que não deve ser pesquisado isoladamente, mas em associação com os demais elementos culturais brasileiros em consonância com as condições sociais compreendidas nos mesmos setores político, econômico e social.

Nas primeiras décadas da república, o contexto de "liberalização institucional" gerou a abertura de novas possibilidades por acreditar-se que o país passava de uma "sociedade fechada" para uma "sociedade aberta" e com isso, a escolarização representava uma possibilidade na esperança de transformações sociais (NAGLE, 1974, p. 99). Isso fez surgir uma grande euforia pela escolarização e um acentuado otimismo pedagógico. $\mathrm{O}$ efeito obtido foi o surgimento de grandes discussões e diversas reformas da escolarização, ao demonstrarse uma preocupação em alterar os padrões de ensino nas instituições escolares, em maior medida na última década da Primeira República. Nagle explica:

O entusiasmo pela educação e o otimismo pedagógico, que tão bem caracterizam a década dos anos vinte, começaram por ser, no decênio anterior, uma atitude que se desenvolveu nas correntes ideias e movimentos político-sociais e que consistia em atribuir importância cada vez maior ao tema da instrução, nos seus diversos níveis e tipos (NAGLE, 1974, p. 101).

Neste sentido, temos em diversas situações a importância dada à instrução escolar, que 
demonstram esse entusiasmo pela educação, como em citações de Rui Barbosa, lidas por Manoel Nogueira nas reuniões noturnas para os negros: “Quem fala com conhecimento está ensinando. O nosso território é imenso, todos devem estudar para defender o Brasil e desbravar as nossas terras" (JESUS, 2014, p. 48). Inclusive, podemos considerar que o senhor Nogueira se constitui enquanto representação de um professor informal, responsável pela formação crítica dos negros daquela cidade, durante as frequentes reuniões que permeiam toda a obra. Na maioria dos momentos em que Bitita faz alusões críticas ao contexto sóciohistórico, suas falas são advindas das referidas discussões com o oficial de justiça.

A professora da autora é representada por meio de uma imagem soberana correspondente justamente à pedagogia escolar das primeiras décadas republicanas, em que o educador assume um papel central na relação pedagógica, e na sociedade como propulsor do entusiasmo pela educação, já que o educador nesse momento ocupava posição de destaque no cenário social que tinha a escola subordinada ao sistema industrial que se desenvolvia: "A acentuação da figura do professor soberano, artífice da formação cultural do povo, vem, paradoxalmente, com a difusão dos argumentos da educação pública popular e esta como mola do progresso econômico e político" (LIBÂNEO, 2012, p. 21).

Nesta perspectiva, pela narrativa dos acontecimentos passados no espaço escolar que a narradora frequentava, reconhecemos uma professora representada a partir de práticas pedagógicas tradicionais, enraizadas no Brasil desde as primeiras experiências pedagógicas com os jesuítas e reverberadas ao longo do Império e no alvorecer da República.

Segundo Libâneo (2012, p.1), nesse contexto do início da República, a pedagogia no Brasil era eclética por reunir as pedagogias católica, herbartiana, intuitiva de Pestalozzi e a visão positivista que vigorava nessa época. Em se tratando mais especificamente do método pedagógico jesuítico, observa-se nas práticas pedagógicas da professora de Bitita, uma filiação à concepção tradicional de ensino, especificamente, na jesuítica, em que professor é aquele que sabe que vai transferir a matéria àquele que não sabe - o aluno (numa posição de passividade), "o professor transfere ao aluno o conhecimento constituído na tradição" (LIBÂNEO, 2012, p. 4).

Além da recepção passiva dos saberes, há uma emulação destacada nas práticas pedagógicas da professora, a partir da competição incitada entre os alunos negros e brancos que nos remete ao método pedagógico dos jesuítas, normatizado pela Companhia de Jesus, no Ratio atque Institutio Studiorum Societatis Jesu, mais conhecido como Ratio Studiorum.O documento tinha o intuito de regulamentar todas as atividades escolares, desde a prática docente, passando pelas questões administrativas até as disciplinares dos discentes. Os 
pressupostos de hierarquia e submissão desta normatização determinavam a posição superior do docente e autorizavam as práticas para manter a ordem no processo de ensinoaprendizagem. De acordo com Carvalho et al (2019, p. 7), “os castigos permaneceram durante a vigência das aulas régias, após a expulsão dos jesuítas, chegando aos séculos XX e XXI esse desejo de modelar o educando pela prática educativa." E para os autores, essa superioridade do professor sobre o aluno é a representação do reflexo da dominação da metrópole sobre a colônia nas relações sociais cotidianas.

Já Ana Maria Melo Negrão (2000) aborda a emulação como um dos aspectos essenciais do método pedagógico dos jesuítas: “arma de incentivo nos certames, debates, desafios, disputas, exposição de trabalhos, premiações, estimulando a entrada em Academias." Também ressalta que os jesuítas não extinguiram por completo os castigos físicos, os quais eram permitidos desde que houvesse justificativa. Na mesma esteira teórica, Franco Cambi (1999, p. 263) compreende que, “apesar da presença de muitos aspectos metodológicos ligados à tradição escolástica, a novidade dos colégios jesuíticos encontra-se na construção de um ambiente educativo rigoroso e coerente, organizado segundo uma severa disciplina, mas aberto para fora através das cerimônias, dos prêmios e das disputas". Nesse sentido, lembramos o episódio citado inicialmente, em que a professora fomenta uma disputa na turma entre os alunos negros e brancos. Ao estabelecê-la, a docente reforçou a competição naturalizada na sociedade, já existente entre eles, que colocava os brancos como superiores, como a própria narradora destacou em outras situações, em mais uma atitude que reitera sua postura tradicional no exercício do magistério.

O desejo da professora de ver seus alunos alfabetizados e realizando as tarefas com dedicação foi traduzido em uma prática que tendia a modelar os estudantes em formas, de igualá-los em um nível considerado o melhor por ela, sem levar em consideração suas particularidades e as consequências que esse estímulo à competição poderia causar.

Ao desenhar no quadro um monstro como forma de ameaçar Bitita, caso não aprendesse a ler, a professora está exercendo seu controle sobre a aluna, buscando disciplinála para o estudo, por meio de uma ação coercitiva. O poder exercido com o intuito de disciplinar indivíduos foi teorizado em Vigiar e punir (2014). A partir da disciplina mantida nas prisões para moldar os corpos dos indivíduos, Michel Foucault mostra que os corpos estão aprisionados por limitações e proibições em muitos outros espaços sociais. Este poder que pode ser exercido sobre o corpo foi descoberto na Época Clássica, segundo o autor, bem como a sua noção de docilidade: o corpo que pode ser submetido, aperfeiçoado, utilizado e transformado. As disciplinas são as formas que possibilitam o controle rigoroso das 
movimentações dos corpos, transformando-lhes em sujeitos dóceis e úteis. Esses processos disciplinares estendem-se para além dos cárceres, por repetição, recordação ou imitação, em instituições como conventos, exércitos, oficinas, hospitais, colégios e escolas primárias. A professora Lonita busca disciplinar seus alunos através do terror.

Somado aos elementos tradicionais apresentados, temos ainda a circunstância do docente estar representado por uma figura feminina e isso não é um acaso. $O$ fato de a profissão ser ocupada majoritariamente por mulheres tem raízes históricas. Se o papel da mulher sempre foi a de educar os filhos, seria "natural" deslocar essa função para a educação formal, "estendendo para fora de casa a tarefa para a qual foi talhada" (LAJOLO; ZILBERMAN, 1999, p. 262). As autoras detalham:

Destinar a mulher ao ensino resolvia diferentes problemas: justificava pragmaticamente a necessidade de educá-la; solucionava a falta de mão-deobra para o magistério, profissão pouco procurada porque mal remunerada; desobrigava o Estado de melhorar os proventos dos professores, porque o salário da mulher não precisava (e nem deveria) ser superior ao do homem, e sim complementar o dele. Essas considerações recobriam-se por outras, de caráter ideológico: idealizava-se a professora, chamando-a de mãe, sugerindo assim que lecionando, ela continuava fiel à sua natureza maternal. Negava-se o elemento profissional da docência, porque a sala de aula convertia-se num segundo lar (LAJOLO; ZILBERMAN, 1999, p. 262).

Temos, portanto, mais uma situação que reforça o conservadorismo marcante na imagem da professora na narrativa.

Em outra situação, embora não tenha sido na representação específica da professora Lonita, a autora mostra o posicionamento político conservador e racista dos professores do início do século XX:

No ano de 1925, as escolas admitiam alunas negras. Mas quando as alunas negras voltavam das escolas, estavam chorando. Dizendo que não queriam voltar à escola porque os brancos falavam que os negros eram fedidos.

As professoras aceitavam os alunos pretos por imposição. Mas se o negro não passava de ano, as mães iam procurar as professoras e diziam:

- A senhora não deixou meu filho entrar no segundo ano porque ele é negro, mas ele já sabe ler e escrever o a-b-c. Os filhos do Júlio Barges passaram de ano, as netas de José Afonso também. Se eu pudesse com mau-olhado estragar a vida de uma professora como a senhora!

As professoras não respondiam. Compreendiam que havia mentalidades opostas. Uma pessoa culta e uma pessoa inculta não chegavam a uma concórdia. Elas diziam que toda profissão tem seu lado negativo. Depois exclamavam:

- Os abolicionistas, veja o que fizeram! Essa gente agora pensa que pode falar de igual para igual. Eu, na época da abolição, tinha mandado essa gente repugnante para a África (JESUS, 2014, p. 43). 
Ao longo da obra, Bitita e outras personagens demonstram atribuir grande importância à formação escolar e mais acentuadamente ao que Marlene Carvalho (2015) conceitua como letramento, o apropriar-se da escrita e da leitura, para usar na vida social, conforme demonstramos: "Porque o Rui disse que esse Brasil grandioso que ele imaginava virá quando não mais existirem analfabetos no nosso torrão. Que o combustível moveu os motores, e o saber locomove o homem." (JESUS, 2014, p. 52). A relevância outorgada ao letramento é reiterada como forma de emancipação e ascensão social. A mesma autora considera que o letramento traz "consequências (políticas, econômicas, culturais etc.) para indivíduos e grupos que se apropriam da escrita, fazendo com que esta se torne parte de suas vidas como meio de expressão e comunicação" (CARVALHO, 2015, p. 65). Logo, a professora que representa a pessoa que tornará possível toda essa apropriação não pode ter senão uma grande relevância na trama narrativa, assim como no espaço social em que ela se encontra, já que a alfabetização "não se concretiza sem o concurso do aparelho escolar, de modo que este se equipa e se estrutura, para atingir aquela meta com eficácia” (ZILBERMAN, 1991, p. 11).

\section{SÍNTESE CONCLUSIVA}

A professora Lonita representa uma educadora bastante tradicional, já de início, por ser representada por uma mulher, e logo, por adotar práticas tradicionais pedagógicas como a jesuítica. Ela adota uma postura autoritária ao exercer seu controle por meio de práticas disciplinares, como os castigos físicos e as ameaças. Por outro lado, a despeito dessa representação conservadora, coerente com o contexto histórico, apresentamos os apontamentos a seguir.

Primeiramente, que a professora representa, a despeito de sua metodologia de ensino, uma posição social de destaque por ser detentora do saber e por proporcionar que os alunos se apropriem da alfabetização como um instrumento de empoderamento, resistência e ascensão social, como reforça Regina Zilberman (1991, p. 74): “Somente uma professora poderia ocupar a posição de passagem entre a elite ilustrada e as camadas populares, porque, de um lado, ela, bem ou mal, exerce o controle sobre um dos aparelhos da cultura - a língua vernácula".

Essa representação bastante tradicional do docente, na trama narrativa, é resultante do momento histórico em que obra está mergulhada e reflexo das práticas pedagógicas exercidas na época, como mostramos ao longo do trabalho. A postura autoritária da professora não deixa de ser uma maneira de inculcar e manter o entusiasmo pela aprendizagem, difundido 
historicamente e transmitido à narradora, que reconhecia sua aprendizagem a partir da leitura em: "Nas horas vagas, eu lia Henrique Dias, Luís Gama, o mártir da Independência, nosso Tiradentes. (...). Lendo, eu ia adquirindo conhecimentos sólidos” (JESUS, 2014, p. 133) e em "Por intermédio dos livros, eu ia tomando conhecimento das guerras que houve no Brasil, a guerra dos farrapos, a guerra do Paraguai”(JESUS, 2014, p. 179).

E por fim, a narradora caracteriza a professora, dona Lonita Solvina, como "saudosa" (JESUS, 2014, 126), a despeito de ter sido vítima de métodos coercitivos de ensino, como o castigo físico, já que foi a educadora que propiciou sua educação formal e a incentivou a estudar. Ter aprendido a ler e a escrever foi revolucionário na vida de Carolina Maria de Jesus: "Eu lia o livro, retirava a síntese. E assim, foi duplicando o meu interesse pelos livros. Não mais deixei de ler." (JESUS, 2014, p. 129) e "Eu ia intelectualizando-me, compreendendo que uma pessoa ilustrada sabe suportar os amarumes da vida”. (JESUS, 2014, p. 179). O letramento foi uma maneira encontrada pela menina para suportar e resistir à marginalização e opressão social imposta pela sociedade.

Mesmo fora do ambiente escolar, em suas peripécias em busca de trabalho e de tratamento para sua enfermidade, ela pode continuar lendo e construiu um repertório significativo, chegando a devorar sozinha, por exemplo, com auxílio apenas de um dicionário, Os Lusíadas. Sua "biblioteca" era formada por livros que eram encontrados na casa dos patrões e que tinham importância central em sua vida: “eu encaixotava meus livros, a única coisa que eu venerava. " (JESUS, 2014, p. 131).

\section{REFERÊNCIAS}

ARFUCH, Leonor. O espaço biográfico: dilemas da subjetividade contemporânea. Rio de Janeiro: Ed UERJ, 2010.

CAMBI, Franco. História da pedagogia. São Paulo: Editora UNESP, 1999.

CARVALHO, Marlene. Alfabetizar e letrar: um diálogo entre teoria e prática. Petrópolis, RJ: Vozes, 2015.

CARVALHO, Maria Elizete Guimarães et al. Dos castigos escolares à construção dos sujeitos de direito: contribuições de políticas de direitos humanos para uma cultura de paz nas instituições educativas. Rio de Janeiro, v.27, n.102, p. 24-46, jan./mar. 2019.

EVARISTO, Conceição. Becos da memória. São Paulo: Pallas, 2017.

FONSECA, Marcus V.; BARROS, S. A. P. (orgs.) A história da educação dos negros no Brasil. Niterói: Ed UFF, 2016. 
FOUCAULT, Michel. Vigiar e punir: nascimento da prisão. Trad. de Raquel Ramalhete. 42 ed. Petrópolis, RJ: Vozes, 2014.

JESUS, Carolina Maria. Diário de Bitita. São Paulo: SESI-SP, 2014.

JESUS, Carolina Maria. Quarto de despejo: Diário de uma favelada. São Paulo: Ática, 2017.

LAJOLO, Marisa; ZILBERMAN, Regina. A formação da leitura no Brasil. 3 ed. São Paulo: Ática, 1999.

LEJEUNE, Philippe. O pacto autobiográfico: de Rousseau à Internet. Org.: Jovita Maria Gerheim Noronha. Belo Horizonte: Editora UFMG, 2008.

LIBÂNEO, José Carlos. Pedagogia tradicional: notas introdutórias. Disponível em: http://professor.pucgoias.edu.br/SiteDocente/admin/arquivosUpload/5146/material/Pedagogia \%20Tradicional\%202012\%202.pdf. Acesso em 03 jun. 2019.

LIMA, Luiz Costa. Mímesis e modernidade: formas das sombras. São Paulo: Paz e Terra, 2003.

LIMA, Luiz Costa. Representação social e mímesis. Rio de Janeiro: Francisco Alves, 1981.

NAGLE, Jorge. Educação e sociedade na Primeira República. São Paulo: Editora Pedagógica e Universitária, 1976.

NEGRÃO, Ana Maria M. Revista Brasileira de Educação. n. 14. Rio de Janeiro. May/Aug. 2000. Disponível em http://www.scielo.br/scielo.php?script=sci_arttext\&pid=S141324782000000200010 . Acesso em 04 jun. 2019.

MORAIS, Christianni. Ler e escrever: habilidades de escravos e forros? (Comarca do Rio das Mortes, Minas Gerais, 1731-1850). In: FONSECA, Marcus V.; BARROS, S. A. P. (orgs.) A história da educação dos negros no Brasil. Niterói: EdUFF, 2016.

RANUM, Orest. Os refúgios da intimidade. In: História da vida privada: da Renascença ao Século das Luzes, v.3. São Paulo: Companhia das Letras, 1991. p. 211-266

SOARES, Magda. Letramento: como definir, como avaliar, como medir. In: SOARES, M. Letramento: um tema em três gêneros. Belo Horizonte: Autêntica, 1998a, p. 61-125.

VEIGA, Cynthia Greive. Promiscuidade de cores e classes: tensões decorrentes da presença de crianças negras na história da escola pública brasileira. In: FONSECA, Marcus V.; BARROS, S. A. P. (orgs.) A história da educação dos negros no Brasil. Niterói: EdUFF, 2016.

ZILBERMAN, Regina (org.) Leitura em crise na escola: as alternativas do professor. Porto Alegre: Mercado aberto, 1991. 